\title{
AANVANGSLEESONDERRIG EN DIE HERSIENE NASIONALE KURRIKULUMVERKLARING
}

\author{
Hannie Menkveld \\ Universiteit van Stellenbosch
}

\begin{abstract}
Sedert die begin van die twintigste eeu, toe onderrig deur medium van Afrikaans in Suid-Afrika ' $n$ aanvang geneem het, is verskeie aanvangsleesbenaderings vir leerders met Afrikaans as moedertaal, bekend gestel en in gebruik geneem. Een so ' $n$ benadering is die psigolinguistiese benadering wat in die sewentigerjare bekendheid begin verwerf het.
\end{abstract}

Een van die psigolinguistiese benaderings, die geïntegreerde benadering, is by uitstek geskik om binne uitkomsgebaseerde onderrig, die basis van die Hersiene Nasionale Kurrikulumverklaring, gebruik te word. In hierdie artikel word twee aanvangsleesmetodes wat gebaseer is op 'n geïntegreerde benadering, die Oxford Storieboomreeks en Ster Stories, met mekaar vergelyk. Daar word veral gelet op hulle versoenbaarheid met leeruitkoms 3 en graad 1 se gepaardgaande assesseringsstandaarde soos vervat in die Hersiene Nasionale Kurrikulumverklaring (Kurrikulum 2005) wat in 2004 in die Grondslagfase in gebruik geneem gaan word (Departement van Onderwys 2002). Die menings van drie graad 1-onderwyseresse word ook by die bespreking betrek.

Since the beginning of the twentienth century, when teaching through the medium of Afrikaans was introduced, a variety of approaches to teaching initial reading have been used for learners whose mother tongue is Afrikaans. One of these approaches is the psycholinguistic approach, which began to gain currency in the seventies.

One of the psycholinguistic approaches, the integrated approach, is by far the most appropriate for outcomes-based education, which forms the basis of the Revised Curriculum Statement In this article, two initial teaching methods, which are based on an integrated approach, the Oxford Storieboomreeks and Ster Stories are compared, particularly with regard to their conciliability with learning outcome 3 and the concomitant assessment standards as set out in the Revised Curriculum Statement (Curriculum 2005). This will be implemented in the Foundation Phase in 2004 (Department of Education 2002). The opinions of three grade 1 teachers form part of the discussion.

\section{INLEIDING}

Aanvangsleesonderrig vorm deel van die leerprogram Geletterdheid, een van die drie leerprogramme van die Grondslagfase. As onderrigleerbenadering vir die onderskeie leerprogramme word Uitkomsgebaseerde Onderrig (UGO), met ' $n$ geïntegreerde benadering as uitgangspunt, deur die Nasionale Onderwysdepartement voorgeskryf. Die doel van so 'n geïntegreerde benadering is dat aktiwiteite so beplan word dat hulle binne konteks as't ware inmekaar gestrengel of verweefd is ('n eenheid vorm) en mekaar gelyktydig aanvul en ondersteun. Die veronderstelling is dat hierdie benadering die bemeestering en ontwikkeling van onder andere die verskillende taalvaardighede, luister, praat, lees en skryf, wat op sigself geïntegreerde vaardighede is, sal verseker. Hierdie vaardighede word doelbewus en kreatief geïntegreerd ingespan om mekaar nie net te ondersteun nie, maar ook om die onderrig en gebruik van taal holisties en funksioneel te hou. Vanuit hierdie perspektief word die daaglikse aktiwiteite in die klaskamer gekenmerk deur betekenis, sinvolheid en leerderbetrokkenheid om te verseker dat die leerders se ervarings en denke maksimaal ontwikkel word. Hierdie vorm die basis van die geletterdheidsproses. 
' $n$ Geïntegreerde benadering is gebaseer op 'n psigolinguistiese benadering met die holistiese ontwikkeling van leerders se vaardighede, kennis, houdings en waardes as doel (Greyling en Joubert sj, Hanekom 1999, Lessing en De Witt 2002, Menkveld 1999, Wessels en Van den Berg 1998). Kenmerke van so 'n geïntegreerde onderrigbenadering is:

- Dis leerdergerig, met die onderwyser in die rol as fasiliteerder

- Leerderbetrokkenheid is van kardinale belang: die klem val op leerderkeuses vir sover dit prakties moontlik is, leerders wat die verantwoordelikheid aanvaar vir hul eie leer en die sinvolle en genotvolle bemeestering van leer/leesinhoude

- Die klem val op betekenisgewing/lees en luister vir betekenis

- Funksionele aktiwiteite vorm die kern van alle implementering

- Die voorkennis/ervarings van die leerders word as verwysingsraamwerk gebruik

- Baie blootstelling aan lewendige, betekenisvolle, outentieke leermateriaal

- Interaksie en kommunikasie met die klem op die vier taalvaardighede en denke is een van die belangrikste uitkomste.

Benewens bogenoemde kenmerke hang die sukses van $n$ geïntegreerde benadering ook af van wat in die klaskamer gebeur tydens die onderrigleersituasie en hoe die klaskamer ingeklee en voorberei is vir hierdie onderrigleersituasie.

Deur die benutting van 'n verskeidenheid aktiwiteite in die onderrigleersituasie poog die onderwyser om onder andere by leerders 'n liefde vir boeke, stories, liedjies en gedigte te laat ontwikkel en om hulle kennis te laat maak met 'n groot verskeidenheid ouditiewe en visuele media.

In sekere gevalle is die onderwyser die aanbieder van die aktiwiteite, soos tydens die voorlees of vertel van bestaande stories of die vertel van eie skeppings. By ander geleenthede is die onderwyser die fasiliteerder. In hierdie rol hanteer sy verskillende strategieë vir begrips- en woordontsluiting asook vir die stimulering van kognitiewe denke.

Tydens hierdie fasiliteringsproses word daar ook van die leerders verwag om self te lees. Self lees vind plaas as die leerders, bv individueel of in pare lees, of met nalees besig is. (Nalees beteken dat die leerder die geskrewe woord/teks volg terwyl iemand, gewoonlik die onderwyser of 'n ander goeie leser, die teks hardop voorlees.) Leerders kan ook self lees deur gebruik te maak van 'n bandspeler: hulle neem hulle eie leespoging op band op en speel die band daarna terug terwyl hulle in hulle boeke volg (nalees) om te kyk of hulle korrek gelees het (Gunning 1996, Menkveld 1995, Wessels en Van den Berg 1998).

Al hierdie aktiwiteite vereis 'n groot verskeidenheid leesstof om leerders se smaak te bevredig en hulle kennis/ervarings uit te brei.

Vanweë die geïntegreerdheid van lees en skryf as onderskeidelik verbale visueel-reseptiewe en verbale visueel-ekspressiewe vaardighede, is skryfonderrig onlosmaaklik aan leesonderrig gekoppel. Daarom moet daar baie geskryf word as deel van die geletterdheidsprogram. Dit sluit alle soorte skryfwerk in: kreatief of skeppend skryf, beheerde skryf (korrekte spelling) en meganies skryf (korrekte lettervorming). Hierdie drie moet in harmonie hanteer word en nie die een ten koste van die ander nie.

Die klaskamer moet 'n omgewing ryk aan geskrewe taal ('print rich') wees wat die leerders blootstel aan 'n groot verskeidenheid geskrewe taal wat bevorderlik is vir die leerleesproses. So 'n klaskamer sal egter ook baie geleenthede bied vir gesprekvoering en dramatisering, die basis vir die ontwikkeling van luister- en praatvaardighede, onderskeidelik verbale ouditief-reseptiewe vaardighede en verbale ouditief-ekspressiewe vaardighede. Vanweë hierdie ouditiewe vaardighede se onlosmaaklike verbintenis aan 'n leerder se visuele vaardighede vorm luister- en praataktiwiteite 'n 
belangrike deel van die geletterdheidprogram. Luisteraktiwiteite moet voorsiening maak vir waarderend luister, aandagtig luister (vir inligting) en krities luister (met die oog op die vorming van 'n eie mening), terwyl praataktiwiteite spontane praat (vertel wat gebeur het), gestruktureerde praataktiwiteite (waar riglyne verskaf word) en voorbereide praataktiwiteite (wat al vier taalaktiwiteite kan insluit) behoort in te sluit.

\section{'n GEİNTEGREERDE BENADERING TOT AANVANGSLEESONDERRIG}

'n Geïntegreerde benadering is gefundeer op die psigolinguistiese benadering en is baie geskik vir aanvangsleesonderrig (Thompson 1997). Die psigolinguistiese benadering is op sigself nie ' $n$ leesmetode met sy kenmerkende voorgeskrewe patroon van aktiwiteite nie, maar ' $n$ aanpakwyse wat eerder berus op 'n studie van die leerder in omgang met taal as kommunikasiemiddel. Dit sluit waarneming in van die leerder tydens sy blootstelling aan genoegsame en motiverende ervaringe met betekenisvolle tekste, wat net so natuurlik is soos om te leer praat. Dit beteken dat selfleer beklemtoon word deurdat daar eers gekyk word na wat die leerder/leser self kan doen met die leesteks. Op grond van hierdie bevindinge sal die onderwyser dan 'n leesaanpakwyse vir die betrokke leerder/leser ontwerp. Die ontwerp gaan afhang van hoe die leerder taal verwerf het, sy agtergrondervaringe, sy natuurlike taalgebruik en bestaande taalvaardighede. Dit neem ook in ag dat die simbole wat 'n leser op papier sien, maar 'n deel is van die totale proses om betekenis te rekonstrueer. Die benadering maak dus voorsiening vir leerders se unieke hantering van die leerleesproses en sy individuele leesstyl wat belangrike konsekwensies het vir aanvangsleesonderrig. (Fisher en Terry 1977, Funnel en Stuart 1995, Greyling en Joubert sj, Gunning 1996, Menkveld 1999).

Volgens Goodman (1997) is lees 'n psigolinguistiese raaispeletjie om betekenis te verkry en nie om meganies woorde, sinne en klanke te herken nie. Dit vereis aktiewe deelname van die leser/leerder om betekenis te konstrueer; iets wat gebaseer is op dit wat die leser weet en glo. 'n Goeie leser kry betekenis deur die gebruik van so min moontlik aanwysingsisteme, inspanning en tyd. Voorspelling en antisipering om betekenis te bekom, eerder as die dekodering van woorde, is 'n belangrike kenmerk van 'n psigolinguistiese benadering.

Die verkryging van begrip is 'n kognitiewe proses. (Kognisie verwys na die wyse waarop die mens inligting inwin omtrent sy wêreld, hoe hy die inligting in kennis verander en voorstel, hoe hy die inligting berg, herwin en gebruik om gedrag te rig.) Daarom is die verkryging of ontwikkeling van kognitiewe strategieë 'n baie belangrike proses vir die beginnerleser. Dit beteken dat die leerder sy eie unieke strategieë moet aanleer om hierdie inwinningsproses vir hom ten beste te laat verloop. Aanvangsleesonderrig behoort sulke geleenthede of aktiwiteite, waar dit gaan oor die ontwikkeling van logiese denke, in te sluit. (Kapp 1990, Louw, Van Ede en Louw 1998).

Hierdie psigolinguistiese benadering is eers in die sewentigerjare volledig beskryf en geniet tans wye steun. Die gebruik van konteks word beskryf as 'n van bo-na-onderproses en word deur die leerder se reeds bestaande kennis van die wêreld, die storie in geheel, die illustrasies en die voorkoms van die boek en buiteblad ondersteun (Riley 1999). Daarom is dit so belangrik dat alle lees binne konteks moet geskied - dit wat gelees word, moet vir die leerder sin maak. Konteks is ook die hoofstrategie om onbekende woorde te identifiseer. Die leerder word aangemoedig om na die eerste letter te kyk en dan te raai wat die woord sê of om die vreemde woord oor te slaan en deur middel van ander inligting uit te vind wat die woord sê. Akkuraatheid word as 'n byproduk gesien omdat die fokus op die verkryging van vaardighede en die verkryging van begrip is. 'n Problematiese aspek is dat dit soms ooreenkomste toon met globale aanvangsleesonderrigmetodes omdat skrywers die vergkryging van betekenis as die basis van beide benaderings beskou (Goodman 1997).

Die onderskeid tussen die verskillende aanvangsleesmetodes berus op die onderliggende teoretiese aannames met oënskynlike uiterstes. Aan die een kant val die klem op transmissie van kennis (soos in die geval van die analistiese, sintetiese of globale metodes) en aan die ander kant 'n meer transaksionele konstruktuvistiese benadering, soos die psigolinguistiese benadering. Twee 
aanvangsleesmetodes wat albei daarop aanspraak maak dat hulle op 'n geïntegreerde of 'n psigolinguistiese benadering gebaseer is, is die Oxford Storieboomreeks en Ster Stories. Hulle word hieronder kortliks bespreek.

\section{Die Oxford Storieboomreeks}

Die Oxford Storieboomreeks is 'n aanvangsleesreeks wat in 1991 in Engels gepubliseer is en in 1994 in Afrikaans verwerk is. In die Onderwysersgids 2 (Du Toit 1996:8) word die benadering as volg beskryf:

In die Oxford Storieboom val die klem op die stories. Die reeks volg 'n holistiese taalbenadering waarin aanvaar word dat taal nie in klein deeltjies verwerf word nie, maar wel as 'n geheel. Die stories stimuleer bespreking asook luister-, lees- en skriftelike aktiwiteite. Dit bied geleentheid vir 'n interaktiewe benadering tot onderrig: sowel leerkrag met leerders as leerders onderling.

Al die boeke in die reeks is deur Roderick Hunt geskryf, deur Alex Brychta geïllustreer en deur Antoinette Stimie in Afrikaans verwerk. Die klem val deurgaans op die stories. Die illustrasies is kleurvol, dikwels humoristies en ondersteun die teks. Op so 'n manier word die leerders gestimuleer om te voorspel wat gaan gebeur en op die gebeure uit te brei.

Daar word van die standpunt uitgegaan dat die leerders se eie rol in die leerproses voorop staan, in dié opsig dat hulle woorde moet herken en begryp, gesuggereerde afleidings kan verstaan en die beelde interpreter. Selfs die leerders wat nog nie gereed is om simbole te interpreteer nie, stel belangstel in stories. Gevolglik sal sommige van dié leerders daartoe in staat wees om 'n storie te interpreteer en weer te gee (Du Toit 1996a, 1996b, Oxford University Press 1996).

Aangesien stories die uitgangspunt van die reeks is, is dit logies dat die leervolgorde Betekenis --Sinne --- Woorde moet wees. Die leerder moet dus eers 'n storie verstaan en sy eie maak voordat daar aandag aan die teks (die korrekte lees daarvan) geskenk kan word.

Die graad 1-leesboeke word in vyf gegradeerde fases verdeel, elkeen met sy eie kleurkodering om maklik tred te kan hou met die leerder se ontwikkeling. Vir elke fase is daar 6 basiese leesboeke (die stamstories) en 6 addisionele boeke (die takke), aangevul deur taakkaarte en werkboeke. Die stories in al die boeke is gebaseer op ' $n$ aantal sentrale karakters. Die hoofkarakters is 'n groep kinders, Vlooi, Biebie en Kalla en hulle hond, Flaffie. Elke boek in die reeks sentreer rondom sommige van die karakters en en vertel 'n storie wat die jonger leerders sal boei en waarmee hulle maklik kan identifiseer. In Fase 1 is die boeke sonder teks. Hulle word gebruik om die karakters bekend te stel. ' $n$ Aantal groot, kleurvolle prente wat dieselfde is as van dié in die boekies vergesel die reeks. Vanaf Fase 2 word teks by die illustrasies gevoeg: aanvanklik slegs een sin per bladsy, wat geleidelik in lengte toeneem tot drie reëls per bladsy in Fase 5. Daar is ook gepoog om die verhaalstruktuur eenvoudig en die teks voorspelbaar te maak sodat veral beginnerlesers daarby sal baat omdat die vermoë om te voorspel wat gaan gebeur bydra tot die ontwikkeling van leesvaardigheid en die leerders dus onmiddellik die genot van lees kan ervaar.

In die stories word daar van natuurlike spreektaal gebruik gemaak. In elke fase is daar 'n groep sleutelwoorde, wat herhaaldelik gebruik word. Die sinstruktuur is gegradeer en word op gekontroleerde wyse aangewend deur die gebruik van 'n aantal sleutelsinne (Du Toit 1996a. 1996b, Oxford University Press 1996).

Die onderrigleerproses behels dat die leerders na die stories luister, oor die teks gesels en na die prente kyk. Hulle vertel die stories oor vir die onderwyser of hulle klasmaats. Veral in graad 1 is dit belangrik dat die ouditiewe en die visuele inhoude met mekaar gekoppel of geïntegreer word. Op so 'n manier leer hulle op 'n genotvolle wyse lees. 
Sleutelwoordeskat word nie geïsoleerd aangeleer nie; die leerders verwerf dit deur daarmee om te gaan binne konteks (in die stories, deur die gebruik van sin- en woordkaarte en speletjies). Die leerders sal op verskillende tye gereed wees om die teks self te lees omdat die reeks saamgestel is om in leerders se individuele behoeftes te voorsien. Die leerder kry die geleentheid om sukses op sy eie vlak te bereik sonder om verveeld te wees deur ander wat stadiger vorder of sonder om 'n mislukking te voel omdat hy/sy nie so vinnig kan lees soos ander nie (Du Toit 1996a, 1996b, Oxford University Press 1996).

Klasbesprekings vorm 'n baie belangrike komponent in die onderrigleersituasie, veral tydens die aanvanklike voorlees van die storie. Die bespreking word gebruik om op grond van die inhoud en interpretasie van die prente en die teks betekenis te gee aan die geskrewe teks, te voorspel wat gaan gebeur, om die inhoud te bevestig en om die gebeure uit te brei. Tydens hierdie proses ontwikkel die leerders se algemene taalvaardighede (luister, praat, lees en skryf) asook hulle kognitiewe vaardighede. Dit moedig die leerders ook aan om hulle eie gedagtes, gevoelens en ervarings met die stories te integreer, wat die interpretasie van die teks vergemaklik. Daarom is dit belangrik om die besprekings dwarsdeur die leesreeks vol te hou.

Die stories en die temas is oor die algemeen relevant en toepaslik, soos uit die meerderheid titels, bv By die skool (Fase 1), Vlooi se verjaardag (Fase 2) en Dis onregverdig (Fase 5) blyk, omdat hulle op die leerders se ontwikkelingsvlak is en by hulle leefwêreld aanpas. Uitsonderinge kom egter voor as gevolg van die verwerking van die reeks in Afrikaans. Dit blyk uit titels soos Die krimpvarkie (Fase 1), Die sneeuman (Fase 3) en Ouma en die Baron (Fase 5). Hierdie temas waaroor die leerders geen of min voorkennis het, is egter verreweg in die die minderheid.

Alhoewel die sigwoorde en sleutelsinne deur speletjies en werkkaarte/werkboeke aangeleer en vasgelê word, moet die leerders hierdie sigwoorde en sleutelsinne dikwels tuis gaan leer. Die leerders word ook individueel getoets om vas te stel watter sleutelsinne, sigwoorde en klanke hy/sy kan lees en watter nie; daarvan word rekord gehou. Leerderbetrokkenheid word gekoppel aan meganiese leer en nie soos hierbo by die kenmerke van 'n geintegreerde benadering uiteengesit is nie. Hierdie werkswyse is eerder kenmerkend van die globale metode as van 'n psigolinguistiese benadering.

\section{Ster Stories}

Ster Stories is 'n reeks boeke wat spesiaal vir aanvangslesers (graad 1-3) geskryf is met die doel om hulle binne 'n geïntegreerde geletterdheidsbenadering te kan gebruik. Met die ingebruikneming van Kurrikulum 2005 met sy UGO-benadering in 1995 (en die Hersiene Nasionale Kurrikulumverklaring vanaf 2004) was dit vir die onderwysers wat die boeke gebruik, gou duidelik dat die Ster Stories by uitstek geskik is vir hierdie benadering.

Die hoofdoel van die boeke is om van beginnerlesers lewenslange lesers te maak. Daar word van die veronderstelling uitgegaan dat leerders leer lees deur baie te lees. Om leerders se leeslus aan te wakker, is 'n wye verskeidenheid tekste, fiksie sowel as nie-fiksie, deur verskillende outeurs geskryf en deur verskillende kunstenaars geïllustreer (Hanekom, Kotzé en Viljoen 1996, Hanekom 1998a, 1999).

Die klem val dus op die lees van baie boeke. Vir graad 1-leerders is daar 60 boeke geskryf wat volgens 10 vlakke gegradeer is. Elke boek bestaan uit 'n kort selfstandige storie met baie en kleurvolle illustrasies. Aanvanklik is daar baie min teks: een sin op 'n dubbelblad wat deur een illustrasie gevul word (vlak 1). Geleidelik word die teks meer: drie tot vier sinne per bladsy (vlak 10). Die stories handel oor 'n groot verskeidenheid temas wat by die leerders se ervarings en voorkennis aansluit en gaan oor karakters wat die hele Suid-Afrikaanse samelewing verteenwoordig, soos uit die volgende titels blyk: Wie se tande is dit? (Vlak 1), Jan maak'n boom (Vlak 4), Toe oupa klein was (Vlak 7) en Boleki (Vlak 10). 
Hierdie boeke is baie geskik vir aanvangsleesonderrig. Dit bevat byvoorbeeld eenvoudige sinskonstruksies met herhalende patrone, die tekste is voorspelbaar en vol humor, die illustrasies help die leser om betekenis te heg aan dit wat hy/sy lees, die kontekste is oor die algemeen bekend aan die leerders en bevat emosies soos blydskap of deernis waarmee die leser kan identifiseer en wat hulle aanmoedig om vir die genot daarvan te lees.

Die boeke word aangevul deur Wenkeboeke vir onderwysers waarin daar 'n verskeidenheid aktiwiteite vir elke boekie gegee word, asook wenke in verband met die integrasie met die ander taalvaardighede, denke en die ander leerareas en die assessering van boekvernuf, klankbewustheid en leesvordering.

Elke boek word as deel van die geletterdheidprogram met die ander taal- en denkvaardighede geintegreer. Die skrywers van die Wenkboek stel voor dat die boeke in die volgende drie onderskeibare, maar opeenvolgende fases hanteer word (Hanekom, Kotzé \& Viljoen 1996).

Voor lees

In hierdie fase word die leerders voorberei op die werklike lees van die betrokke Ster Storie. Aspekte soos die konteks van die storie, relevante agtergrondinligting, die betekenis van die woordeskat in die boek, die voorbereiding vir die lees van die woorde en sinne in die boek (dikwels word 'n nuwe woord voor die leerders op 'n flitskaart geskryf: die leerders sê wat die onderwyseres moet skryf), oefeninge in verband met klankbewustheid, die aanleer van klanke en die spelling van woorde, kry alles as deel van die klasbesprekings aandag. Hierdie fase kan oor meer as een sessie versprei word, veral as dit met die res van die geletterdheidsprogram geintegreer word.

Die voor-lees-fase met sy interaksie en leerderbetrokkenheid is 'n baie belangrike fase en een wat beslis nie oorgeslaan mag word nie. Dit is volgens Anderson (in Hanekom 1996) ...the single most important activity for building the knowledge required for eventual success in reading. Hanekom (1996) noem die volgende voordele van die voor-lees-fase: dit help leerders om beter te presteer in aanvangslees; dit help leerders met die ontwikkeling van luistervaardighede; dit verbeter leerders se vermoë om op hulle eie te lees, brei hulle woordeskat uit en verbeter hulle leesbegrip sowel as praaten skryfvaardighede.

\section{Tydens lees}

Gedurende hierdie fase word die betrokke Ster Storie aan die leerders voorgelees deur die onderwyser of 'n ander geskikte persoon, bv 'n ouma of 'n oupa. Die titel en voorblad van die boek word bespreek asook die illustrasies op elke bladsy van die boek. Die leerders word gevra om voorspellings en afleidings oor die tema en die storie te maak. Die storie as 'n geheel is baie belangrik en daarom moet die leerders die inhoud van die storie ken en begryp voordat hulle die boek self lees. Sodra die leerders in hierdie opsigte gereed is, kan hulle die boek self probeer lees: nalees, in pare lees en individule lees word afgewissel. Dit is in die meeste gevalle wenslik dat die onderwyser of 'n goeie leser die boek eers saam met die leerders hardop lees: dit versterk die stadiger lesers se leesvermoë.

\section{Na lees}

Nadat die leerders die Ster Storie op allerlei maniere gelees het, vind 'n verskeidenheid opvolgaktiwiteite gebaseer op interaksie, nadenke, refleksie, inoefening en vaslegging, plaas.

Voorbeelde van sinvolle opvolgaktiwiteite is

- relevante opdragte oor die boek (tema) wat luister-, skryf-, praat- en ander leesaktiwiteite betrek

- die inoefening en toepassing van nuwe woordeskat en begrippe op 'n funksionele wyse, bv eie stories lees en skryf, woordspeletjies, taalspeletjies, rolspel

- aktiwiteite wat by ander leerareas pas en daarmee geïntegreerd is, bv die tema van die boek word gebruik as tema van al drie leerprogramme vir die tydperk wat aan die boek afgestaan word. 


\section{BESPREKING}

Die Oxford Storieboomreeks sowel as die Ster Stories is geskik om binne 'n UGO-benadering gebruik te word omdat albei sterk steun op die kernbeginsels van die UGO, nl integrasie en leerders se holistiese (taal)ontwikkeling teen die individu se eie tempo.

Die leermateriaal (leesboeke, wenkeboeke vir onderwysers en, in die geval van die Oxford Storieboomreeks, die sins- en woordkaarte, werkboeke en taakkaarte) is beide gevalle relevant en toepaslik, want sowel die begripsaspekte as die meganiese leesvaardighede (sins-, woord- en klankherkenning) is op die leerders se ontwikkelingsvlak en voorkennis toegespits. Die leesboeke van albei benaderings is in volkleur gedruk met treffende illustrasies wat motivering en leeslus behoort aan te wakker.

Die belangrike rol wat besprekings speel, verseker dat daar volop geleentheid geskep word vir leerderbetrokkenheid en wel op so 'n manier dat alle leerders, ook die stadige lesers, 'n sekere mate van sukses ervaar. Sonder die besprekings en geleenthede vir betekenisskepping sal die leerders sukkel om die tekste te lees.

Beide aanvangsleesmetodes maak sowel deur die vlak waarop die besprekings plaasvind, as deur die gradering van die leesmatriaal ruim voorsiening vir progressie in sowel die leerders se begrips- en denkvermoë as die moeilikheidsgraad van die leesmateriaal self. Daar is ook ruim geleentheid, onder andere deur die groot verskeidenheid stories, vir leerders om aan bepaalde vaardighede, houdings, waardes en kennis van die inhoude blootgestel te word en dit self te verwerf.

Alhoewel daar in die Oxford Storieboomreeks vanuit 'n geintegreerde perspektief op leer gefokus word, kan die reeks egter nie beskou word as een wat op 'n psigolinguistiese benadering gebaseer is nie. Van die belangrikste onderskeidende kenmerke van 'n psigolinguistiese benadering, die leerders se volledige betrokkenheid by hulle eie leer (engagement) soos hierbo beskryf, ontbreek. Die gestruktureerde aanbieding van die voorgeskrewe kernwoordeskat en sleutelsinne wat al die leerders moet kan lees, asook die voorbereide oefeninge in die werkboeke en op die werkkaarte, bring mee dat hierdie reeks veel meer na 'n globale benadering met ingeboude integrasiebeginsels neig.

Die Ster Stories se teoretiese onderbou is van so ' $\mathrm{n}$ aard dat anvangsleesonderrig met hierdie boeke op 'n psigolinguistiese benadering berus. Die moontlikheid bestaan wel dat die onderwyseres wat die boeke gebruik, nie genoegsame kennis dra van die genoemde psigolinguistiese beginsels nie en die onderrigleersituasie slegs vanuit 'n globale geïntegreerde perspektief benader. Die suksesvolle hantering van Ster Stories binne 'n psigolinguistiese benadering hang dus grotendeels van die onderwyseres af.

\section{Die onderwyseresse}

Om meer te wete te kom oor die praktykervaringe van onderwyseresse met hierdie twee aanvangsleesmetodes, is onderhoude gevoer met drie graad 1-onderwyseresse van drie verskillende skole wat respektiewelik 15, 17 en 18 jaar ondervinding in 'n graad 1-klas het. Volgens hulle gebruik al drie 'n geïntegreerde benadering tot leesonderrig al vir 4,8 of 10 jaar.

Twee van die skole gebruik Ster Stories en een die Oxford Storieboomreeks. Ongeag watter metode hulle gebruik, is al drie onderwyseresse dit eens dat die aanvangsleesmetode wat hulle gebruik, baie geskik is vir UGO, veral omdat hulle van mening is dat die boeke hulle baie goed leen tot die uitwerk van ' $n$ verskeidenheid geïntegreerde aktiwiteite. Die uitkomsgebaserde benadering en die aard van die leesstof ontlok volgens hulle meer as enige ander benadering baie belangstelling by die leerders en lewer die beste resultate ten opsigte van die ontwikkeling van begrip en die aanleer van die meer meganiese leesvaardighede. Hierdie voordele berus egter hoogstens op die moontlikheid tot integrasie van die verskillende taalvaardighede binne die geletterdheidsleerprogram. 
Slegs een van die onderwyseresse (wat Ster Stories gebruik en wat een van die projekskole was) het laat blyk dat sy bewus is van die onderliggende filosofie ('n psigolinguistiese benadering) van die Ster Stories. Ten spyte daarvan benut sy die psigologiese beginsels slegs gedeeltelik, hoofsaaklik omdat sy van mening is dat die leerders in die skool se agtergrond, ervaring en voorkennis van so 'n aard is dat hulle in graad 1 nog te jonk is om verantwoordelikheid vir hulle eie leer te aanvaar.

Al drie onderwyseresse is van mening dat die betrokke leesreeks (Oxford Storieboom) of leesboeke (Ster Strories) en die gepaardgaande aanvangleesmetode wat hulle skool gebruik, die een is wat hom volgens hulle die beste tot aanvangsleesonderrig leen. Geeneen van die onderwysers sou iets of baie min aan die metodes in sy geheel wou verander. Nogtans het almal gesê dat hulle sterk steun op hulle eie ervaring as dit kom by die keuses wat hulle moet mak ten opsigte van die manier waarop hulle die boeke met hulle klas gebruik

Aangesien al drie ervare onderwyseresse is, gebruik hulle die breë implementeringsriglyne soos vervat in die Onderwysersgids (Oxford Storieboom) of die Wenkeboek (Ster Stories), maar sonder om voortdurend daarop terug te val. Die leerders se behoeftes en hulle eie ervaring, inisiatief, innoverende denke en kreatiwiteit sorg daarvoor dat hulle die leesboeke met groot effektiwiteit binne UGO, as 'n geïntegreerde benadering. Dit lyk dus of persoonlike voorkeur en ervaring 'n deurslaggewende rol speel ten opsigte van die wyse van implementering van sowel die Oxford Storieboomreeks of die Ster Stories.

Die vraag is of die onderwyseresse se keuse van die Oxford Storieboomleesreeks of die Ster Storieboeke vir hulle skool (as senior onderwyseresse het hulle mening 'n deurslaggewende rol gespeel by die finales keuse) enigsins bepaal is deur die teoretiese fundering van die betrokke leesreeks/boeke en die gepaardgaande metode van anvangsleesonderrig. Op die oog af lyk dit asof hulle nie oor genoegsame kennis/opleiding beskik het om 'n ingeligte keuse in hierdie verband te maak nie, alhoewel al drie wel hierdie menings toegedaan was. Dit lyk na 'n fundamentele probleem wat daartoe sou kon bydra tot onderwyseresse se moontlike oppervlakkige perspektiewe op aanvangleesonderrig: 'n geïntegreerde benadering sou maklik beskou kon word as die integrasie van taalvaardighede en ander aktiwiteite in plaas van die psigolinguistiese beskouing dat die integrasie ' $n$ fundamentele deel van die aanpakwyse behoort te vorm. Hierdie mening word versterk deur die onvoldoende opleiding wat al drie onderwyseresse gesê het hulle in UGO gehad het.

\section{Die Hersiene Nasionale Kurrikulumverklaring}

Die Hersiene Nasionale Kurrikulumverklaring word vanaf 2004 in die Grondslagfase ingevoer. Om die suksesvolle inplementering te verseker behoort daar voldoende indiensopleiding aan onderwysers gegee te word; iets wat blykbaar tydens die implementering van Kurrikulum 2005 agterweë gebly het. Een belangrike aspek waaraan in die opleiding aandag gegee sal moet word, is die implementering van UGO in die klaskamer. Dit gaan in die besonder daaroor om te kan vasstel of die benaderings met sy spesifieke metodes tot aanvangsleesonderrig wat in skole gebruik word, geskik is om leeruitkoms 3 (lees en kyk) en sy gepaardgaande assesseringskriteria te bereik.

Met die oog op die vasstel of die onderhawige twee aanvangsleesonderrigmetodes versoenbaar is met die Hersiene Nasionale Kurrikulumverklaring, word die relevante gedeeltes hieronder aangehaal.

Die uitkomste en assesseringstandaarde beklemtoon deelnemende, leerdergerigte en aktiwiteitsgebaseerde onderwys. Dit laat groot ruimte vir kreatiwiteit en vernuwing deur onderwysers in die vertolking van wat en hoe hulle onderrig (Oorsig, Departement van Onderwys, 2002a: 19).

\section{LEES EN KYK: (Leeruitkoms 3)}

Die leerder is in staat om vir inligting en genot te lees en te kyk en krities op die estetiese, kulturele en emosionele waardes in tekste te reageer (Tale (Afrikaans - Moedertaal), Departement van Onderwys, 2002b: 19). 
Dit is duidelik wanneer die leerder die volgende doen: (Assesseringstandaarde vir graad 1)

- Gebruik visuele leidrade on betekenis te skep

- Rolspeel lees

- Skep betekenis uit geskrewe tekste

- Begin om letters en woorde te herken en betekenis daaruit te skep

- Begin om klankbewustheid te ontwikkel

- Lees vir inligting en genot (Tale (Afrikaans - Moedertaal), Departement van Onderwys, 2002b: 18-20).

As bogenoemde aanhalings met die bevindinge uit die literatuur en op grond van die menings van die onderwyseresse vergelyk word, is dit duidelik dat die behaling van sukses en die bereiking van Leeruitkoms 3 nie vanselfsprekend is nie. (Dié siening word bevestig deur die resultate van die Nasionale Verslag oor Geletterdheid in die Grondslagfase wat op 9 Junie 2003 deur die Minister van Onderwys vrygestel is, wat aandui dat slegs $54 \%$ van die graad 3 -leerders geletterd is.)

Albei aanvangsleesmetodes is geskik is om binne UGO as deel van 'n geletterdheidsprogram in die Grondslagfase gebruik te word, aangesien albei die moontlikheid bied vir die bereiking van leeruitkoms 3 met sy onderskeie komponente, soos lees vir inligting, genot en leerders se kritiese reaksie op die estetiese, kultureke en emosionele waardes in die tekste, al is dit op 'n elementêre vlak. Slegs Ster Stories het die potensiaal tot deelnemende, leerdergerigte en aktiwiteitsgebaseerde onderwys soos die Nasionale Kurrikulumverklaring dit bedoel. Of dit gerealiseer sal kan word, sal waarskynlik van die klasonderwyser self afhang, want soos die drie betrokke onderwyseresse gesê het, is inisiatief en ervaring nodig om innoverend en kreatief met die leesstof om te gaan. Onderwyseresse het verder ook bepaalde insigte en kennis van die psigolinguistiese benadering nodig sowel as die kennis en vaardighede om hulle werkwyse aan te pas by die individuele behoeftes van die leerders.

As die assesseringsstandaarde een vir een in oënskou geneem word, val dit op dat daar in die Wenkeboeke van die Ster Stories eksplisiet melding gemaak word van die meeste van hierdie assesseringsstandaarde; nie as assesseringsmiddele nie, maar as deel van die leesonderrigproses. Enkele voorbeelde:

- Tydens die voor-lees-fase word visuele leidrade doelbewus betrek om betekenis te heg aan die teks.

- Verskillende maniere van lees, soos rolspel, word deurgaans sterk aanbeveel.

- Die herkenning van letters en klanke word sterk beklemtoon tydens die voor-lees-fase.

- Klankbewustheid word as 'n afsonderlike aktiwiteit tydens die voor-lees-fase hanteer vanweë sy belangrike rol vir klankleer en spelling.

- Die aard van die boeke voorsien voldoende geleenthede om verskillende soorte tekste, bv. vir genot en die verskaffing van inligting te lees.

Alhoewel die Onderwysersgids vir die Oxford Storieboomreeks die meeste van hierdie vaardighede en aktiwiteite nie eksplisiet genoem nie, sal die ervare onderwyseres wel in staat wees om die nodige aanpassings te maak om hierdie assesseringsstandaarde ook by Geletterdheidsleerprogram in te sluit.

\section{SLOTSOM}

In hierdie artikel is twee aanvangsonderrigmetodes, die Oxford Storieboomreeks en Ster Stories, as voorbeelde van geïntegreerde aanvangsleesbenaderings, gefundeer op 'n psigolinguistiese benadering, bekendgestel en teen die agtergrond van die menings van drie ervare onderwyseresse en die betrokke gedeelte van die Hersiene Nasionale Kurrikulumverklaring bespreek. 
Daar is tot die gevolgtrekking gekom dat albei metodes binne 'n UGO-raamwerk, soos voorgeskryf deur die Hersiene Nasionale Kurrikulumverklaring, gebruik kan word, maar dat die Oxford Storieboomreeks nie op die psigolinguistiese benadering gefundeer is nie. Waar die Wenkeboek van die Ster Stories genoegsame geskikte voorbeelde gee van aktiwiteite wat in lyn is met die assesseringstandaarde vir die onderwyseres om te gebruik, is dit nie die geval by die Oxford Strorieboomreeks nie. Die Oxford Storieboomreeks gaan gevolglik 'n groter aanspraak maak op die ervaring, innoverende denke en kreatiwiteit van die betrokke onderwyseres as dit kom by die hantering van die leerders se vaardighede soos dit aan die betrokke assesseringsstandaarde gemeet behoort te word. Dit behoort eerder as 'n uitdaging as 'n onoorkomlike probleem beskou te word.

\section{ERKENNING}

Ek wil graag vir Adél Lerm (BEdHons-student, 2001) bedank vir haar belangrike aandeel aan hierdie studie. Die navorsing wat sy as deel van die BEdHons-program gedoen het, vorm die kern van hierdie artikel.

\section{VERWYSINGS}

DEPARTEMENT VAN ONDERWYS. 2002a. Hersiene Nasionale Kurrikulumverklaring Graad R-9 (Skole): Oorsig. Pretoria: Departement van Onderwys.

DEPARTEMENT VAN ONDERWYS. 2002b. Hersiene Nasionale Kurrikulumverklaring Graad R-9 (Skole): Tale (Afrikaans - Moedertaal). Pretoria: Departement van Onderwys.

DU TOIT A. 1996a. Oxford Storieboom: Onderwysergids 1. Kaapstad: Oxford University Press.

DU TOIT A. 1996b. Oxford Storieboom: Onderwysergids 2. Kaapstad: Oxford University Press.

FEENEY S, CHRISTENSEN D \& MORAVICK B. 1996. Who am I in the lives of children. Englewood Cliffs, NewJersey: Prentice Hall Inc. Simon \& Schuster Co.

FISHER CJ AND TERRY CA. 1977. Children's language and the Language Arts. VSA: Mc GrawHill Book Company.

FUNNEL F AND STUART M. 1995. Learning to read: Psychology in the classroom. Oxford UK \& Cambridge USA: Blackwell.

GOODMAN KS. 1997. The Teaching of Reading: Encyclopedia of Language and Education. Vol 2: Literacy 1-7. Edwards V. \& Corson D. (eds.). Netherlands: Kluwer Academic Publishers.

GREYLING PJ EN JOUBERT JJ. sj. Vakdidaktiek van leesonderrig vir die Junior Primêre Fase. Pretoria: De Jager-HAUM Uitgewers.

GUNNING TG 1996. Creating reading Instruction for all children. VSA: Ally and Bacon Publishers.

HANEKOM A, KOTZÉ H \& VILJOEN R. 1996. Ster Stories: 'n Wenkeboek vir aanvangslees met kinderboeke. Kenwyn: Juta \& Kie.

HANEKOM A EN KOTZÉ H. 1996. Ster Stories: 'n Wenkeboek vir die tweede skooljaar. Kenwyn: Juta \& Kie.

HANEKOM A. 1998a. Ster Stories: 'n Wenkeboek vir die tweede skooljaar (Nuwe Kurrikulum 2005 uitgawe). Kenwyn: Juta \& Kie. 
. 1998b. Ster Stories: 'n Wenkeboek vir die derde skooljaar. Kenwyn: Juta \& Kie. 1999. Ster Stories: Stap vir stap deur Kurrikulum 2005. Kenwyn: Juta \& Kie.

KAPP JA (red). 1990. Kinders met probleme: 'n Ortopedagogiese perspektief. Pretoria: Van Schaik Uitgewers.

LESSING AC EN DE WITT MW. 2002. Teaching reading in an OBE framework. SAVTO 36 (3\&4): 273-287.

LOUW DA, VAN EDE DM \& LOUW AL. 1998. Menslike Ontwikkeling. Pretoria: Kagiso Uitgewers.

MENKVELD H. 1995. Klasnotas: Leesonderrig. Departement Didaktiek, Universiteit van Stellenbosch. Stellenbosch

OXFORD UNIVERSITY PRESS. 1996. Katalogus: Oxford Storieboom. Kaapstad: Oxford University Press.

RILEY J. 1999. Teaching Reading at Key Stage 1 and before. Cheltenham, UK: Stanley Thomas (Pub.) Ltd.

THOMPSON GB. 1997. The Teaching of Reading: Encyclopedia of Language and Education. Vol 2: Literacy. Edwards V. \& Corson D. (eds.). Netherlands: Kluwer Academic Publishers: 9-17.

WESSELS M AND VAN DEN BERG R. 1998. Practical guide to facilitating language learning: Methods, activities \& techniques for OBE. Johannesburg:International thomsom Publishing (Southern Africa) (Pty) Ltd.

\section{Biografiese nota:}

Dr Hannie Menkveld is hoof van die Afdeling Afrikaans, Departement Didaktiek, aan die Universiteit van Stellenbosch (epos: HMENK@sun.ac.za) 